JURNAL ILMU KESEHATAN BHAKTI HUSADA:

HeALth SCIENCES JouRnAL, Vol. 10 No. 01, DeSEMBER 2020

DOI: $10.34305 /$ jikbh.v11i2.184
Ciptaan disebarluaskan di bawah

Lisensi Creative Commons Atribusi-

NonKomersial-BerbagiSerupa 4.0

Internasional

\title{
SISTEM PROTEKSI AKTIF DAN SARANA PENYELAMATAN JIWA DARI KEBAKARAN DI RSUD KABUPATEN BEKASI
}

\author{
Melia Listia Sari, Tatan Sukwika \\ Universitas Sahid Jakarta \\ tatan.swk@gmail.com
}

\begin{abstract}
Abstrak
Sebagai fasilitas umum, gedung RSUD harus dapat mengidentifikasi dari potensi bahaya kebakaran, oleh karena itu diperlukan sistem proteksi kebakaran. Upaya sebenarnya adalah penerapan sistem proteksi kebakaran dengan prosedur, termasuk sistem proteksi aktif dan fasilitas penyelamat jiwa. Penelitian ini bertujuan mengidentifikasi penerapan sistem proteksi aktif dan fasilitas penyelamatan jiwa serta keandalan keamanan bangunan terhadap kebakaran. Metode penelitian yang digunakan deskriptif kualitatif untuk mengungkap peristiwa atau fakta dan keadaan yang terjadi sesuai dengan kondisi di lapangan. Sehingga dibutuhkan observasi dan wawancara langsung dengan informan untuk mendapatkan data. Hasil menunjukkan bahwa nilai kondisi penerapan sistem proteksi aktif sebesar 17,04\%, nilai komponen fasilitas penyelamatan jiwa sebesar 23,25\%, dan nilai keandalan keamanan gedung sebesar $87,48 \%$. Kesimpulan secara keseluruhan bahwa komponen proteksi aktif, kondisi fasilitas penyelamat jiwa dan keandalan keselamatan kebakaran gedung menunjukkan nilai reliabilitas dalam kategori "B" Baik. Pada sub komponen sistem proteksi aktif belum semua saran tersebut diatas dimiliki atau terpasang di setiap gedung di RSUD. Oleh karena itu, ke depan secara bertahap, untuk antisipasi terjadinya kebakaran perlu dilengkapi sarana pendukung sistem proteksi aktif dan dilakukan commissioning test terhadap lift kebakaran.
\end{abstract}

Kata Kunci: Sistem proteksi aktif, kemampuan keselamatan gedung, sistem proteksi kebakaran, fasilitas penyelamatan. 
JURNAL ILMU KeSEHATAN BHAKTI HUSADA:

HEALTH SCIENCES JouRnal, VOL. 10 No. 01, DeSEMBER 2020

DOI: $\underline{10.34305 / j i k b h . v 11 i 2.184}$
Ciptaan disebarluaskan di bawah

Lisensi Creative Commons Atribusi-

NonKomersial-BerbagiSerupa 4.0

Internasional

\section{Pendahuluan}

Gedung atau bangunan merupakan sarana dan prasarana umum atau infrastruktur Sukwika (2018) untuk mendukung aktivitas manusia yang terbentuk melalui proses perencanaan pelaksanaan konstruksi hingga kegiatan yang berkaitan proteksi dan pencegahan dari bahaya kebakaran. Peristiwa kebakaran dapat terjadi di jenis bangunan apapun, baik di pemukiman, perindustrian, rumah sakit, atau di gedung atau bangunan lainnya. Kejadian kebakaran menyebabkan berbagai kerugian baik materil maupun non materi, bahkan bisa merenggut nyawa yang berada pada lokasi terjadinya kebakaran. Salah satu penyebab kebakaran antara lain dampak penggunaan energi seperti listrik, bahan bakar, tabung oksigen,bahan kimia atau lainnya. Inilah yang dapat berpotensi terjadinya bahaya kebakaran (Kowara, R. A., \& Martiana, 2017).

Rumah sakit salah satu sarana publik yang rentan terhadap potensi bahaya kebakaran (Hambyah, 2016; Safaat, 2015; Simangunsong, 2017). Penyebab utama kasus kebakaran di rumah sakit adalah akibat hubungan arus pendek listrik dan penggunaan kompor (Ramli, 2010; Simangunsong, 2017).
Rumah sakit merupakan sarana umum pelayanan kesehatan bagi masyarakat sehingga harus terbebas dari bahaya kebakaran. Dalam hal mencegah dan menanggulangi kebakaran dibutuhkan suatu sistem proteksi kebakaran yang sesuai dengan standar sehingga dapat mendeteksi dan meminimalisir bahaya kebakaran di rumah sakit (Kowara, R. A., \& Martiana, 2017; Septiadi et al., 2014; Simangunsong, 2017; Vanisia, 2017).

Rumah sakit yang memberikan pelayanan kesehatan umum seperti di RSUD Kabupaten Bekasi memiliki berbagai fasilitas pelayanan kesehatan yang beragam diantaranya poli anak, ruang rawat inap, IGD, radiologi, laboratorium, pos bersalin, poli paru dan lain sebagainya. Dalam menjalankan operasional pelayanan kesehatan, RSUD kabupaten Bekasi menggunakan berbagai alat yang rentan dapat menjadi sumber bahaya kebakaran seperti diantaranya sistem instalasi listrik, penggunaan alat-alat kesehatan yang menggunakan listrik dalam kapasitas besar, bahan-bahan kimia yang mudah terbakar dan penggunaan kompor gas. Disebutkan Permen PU nomor 26 tahun 2008, bahwa bahaya kebakaran akibat adanya ancaman potensial terkena pancaran api yang menimbulkan asap dan gas (PermenPU, 
JURNAL ILMU KeSEHATAN BHAKTI HUSADA:

HEALTH SCIENCES JOURNAL, VOL. 10 No. 01, DESEMBER 2020

DOI: $\underline{10.34305 / j i k b h . v 11 i 2.184}$
Ciptaan disebarluaskan di bawah

Lisensi Creative Commons Atribusi-

NonKomersial-BerbagiSerupa 4.0

Internasional
2008). Bentuk antisipasi terhadap bahaya kebakaran di RSUD kabupaten Bekasi adalah menerapkan sistem proteksi terhadap kebakaran yang sesuai prosedur (Asyroffi, 2017; BSNI, 2000e). Sebuah proteksi kebakaran yang baik harus tersistem mulai dari peralatan, kelengkapan, dan sarana. Ketiganya harus terpasang dan terbangun pada bangunan rumah sakit. Selain sistem proteksi aktif, rumah sakit harus dilengkapi pula dengan sistem proteksi pasif seperti sarana penyelamatan jiwa (BSNI, 2000f; OHSAS, 2007; Rahman, 2017; Ramli, 2010; Rijanto, 2010; Vanisia, 2017).

Lingkup penelitian ini berfokus pada sistem proteksi aktif dan sarana penyelamatan jiwa. Sementara sistem proteksi pasif di rumah sakit umumnya merupakan bangunan permanen yang sudah sesuai standar konstruksi sistem proteksi pasif yang tahan api (BSNI, 2000b; KepmenNaker, 1999; Permenkes, 2010; PermenPU, 2008). Lebih lanjut, keunggulan keberadaan sarana proteksi aktif dianggap efisien dalam pengurangan kejadian kebakaran dan penghuni gedung lebih mudah untuk memadamkan api. Keberadaan sarana proteksi aktif juga dapat membantu memudahkan petugas pemadam kebakaran melakukan pemadaman api (Septiadi et al., 2014). Keberadaan sarana penyelamatan jiwa menjadi aspek penting dan berfungsi baik sehingga memudahkan proses evakuasi dan penyelamatan mengingat rumah sakit merupakan tempat yang banyak dihuni oleh orang sakit yang lemah dan tidak dapat menyelamatkan dirinya sendiri. Tujuan penelitian melakukan pengidentifikaian terhadap penerapan sistem proteksi aktif dan fungsi sarana penyelamatan jiwa, serta menilai keandalan keselamatan bangunan gedung terhadap kebakaran sesuai standar Pd-T-112005-C yang diberlakukan di RSUD Kabupaten Bekasi.

\section{Metode}

Pelaksanaan penelitian pada bulan November 2019 sampai dengan Januari 2020. Lokasi penelitian dilakukan di RSUD kabupaten Bekasi, Provinsi Jawa Barat. Pendekatan penelitian dengan deskriptif kualitatif, dimana pengungkapan kejadian atau fakta, keadaan, fenomena, faktor dan keadaan yang terjadi dengan sebenarnya sesuai kondisi di lapangan. Penelitian ini memberikan informasi berupa deskripsi implementasi sistem proteksi kebakaran aktif dan sarana penyelamatan jiwa di RSUD Kabupaten Bekasi. Metode yang studi ini adalah deskriptif kualitatif 
JURNAL ILMU KeSEHATAN BHAKTI HUSADA:

HEALTH SCIENCES JOURNAL, VOL. 10 No. 01, DESEMBER 2020

DOI: $\underline{10.34305 / j i k b h . v 11 i 2.184}$
Ciptaan disebarluaskan di bawah Lisensi Creative Commons Atribusi-

NonKomersial-BerbagiSerupa 4.0

Internasional digunakan untuk mendeskripsikan suatu hasil objek yang dikaji (Sugiyono, 2013).

Proses pengumpulan data berupa wawancara dan observasi langsung. Pengamatan observasi dilakukan terhadap kondisi komponen sistem proteksi aktif dan sarana penyelamatan jiwa di RSUD kabupaten Bekasi. Pedoman standar pemeriksaan keselamatan bangunan gedung dari kejadian kebakaran yang digunakan adalah Pd-T-11-2005-C (BSNI, 2004). Sedangkan wawancara dilakukan kepada narasumber untuk memperoleh informasi tentang objek permasalahan yang sedang diteliti di RSUD Kabupaten Bekasi. Tabel 1 menyajikan kriteria penilaian kondisi setiap komponen bangunan sesuai Pd-T-11-2005C (BSNI, 2004; PermenPU, 2008).

Tabel 1. Tingkat Penilaian

\begin{tabular}{cll}
\hline Nilai & \multicolumn{3}{c}{ Kesesuaian } & \multicolumn{1}{c}{ Keandalan } \\
\hline$>80-100$ & Sesuai semua & (B) Baik \\
$60-80$ & $\begin{array}{l}\text { Sesuai sebagian besar dan terdapat sebagian kecil } \\
\text { instalasi tidak sesuai } \\
\text { Tidak sesuai sebagian besar }\end{array}$ & (C) Cukup \\
$<60$ & (K) Kurang
\end{tabular}

\section{Hasil Dan Pembahasan}

\section{Sistem Proteksi Aktif Kebakaran}

Ada 13 sub-komponen yang diteliti, berikut hasilnya:

Deteksi dan alarm. Sistem deteksi otomatis dan alarm kebakaran untuk pencegahan bahaya kebakaran di lapangan harus sesuai SNI 03-3985-2000 (BSNI, 2000e, 2000f). Pada seluruh bangunan gedung di RSUD kabupaten Bekasi sudah dipasang alat heat detector yang terhubung langsung dengan alarm kebakaran. Tersedia pula alat picu alarm manual berjarak kurang dari 30 meter. Sistem detektor dalam kondisi dan berfungsi baik.

APAR. Tersedia APAR pada seluruh bangunan gedung, Pada APAR terlihat jelas jenis APAR dan klasifikasi api yang dapat dipadamkan. Terdapat petunjuk penggunaan APAR dan label pemeriksaan yang ditempel di tempat APAR. Kondisi APAR baik dan berfungsi dan diletakkan di tempat yang mudah terlihat. Kondisi ini menunjukkan terdapat kesesuaian pemasangan APAR dengan standar Permenakertrans nomor 3 Tahun 1980 (Permenakertrans, 1980). APAR yang aman dan ramah lingkungan yang berisi gas cair dan rutin lakukan pengisian ulang APAR kadaluarsa (Hambyah, 2016).

Hidran. Jaringan pipa hidran dipasang dengan baik dan sesuai standar pemasangan. Peletakan hidran halaman mudah terjangkau oleh mobil pemadam 
JURNAL ILMU KeSEHATAN BHAKTI HUSADA:

HEALTH SCIENCES JOURNAL, VOL. 10 No. 01, DESEMBER 2020

DOI: $\underline{10.34305 / j i k b h . v 11 i 2.184}$
Ciptaan disebarluaskan di bawah

Lisensi Creative Commons Atribusi-

NonKomersial-BerbagiSerupa 4.0

Internasional kebakaran, seperti berada di jalan masuk, jalan keluar, dan halaman RSUD (BSNI, 2000c, 2000d). Di sekitar alat hidrant terdapat tanda petunjuk hidran. Pipa atas berfungsi baik untuk menyambungkan selang dan mengalirkan air. Pelaksanaan teknis pencegahan bahaya kebakaran pada bangunan gedung melalui tata cara pemasangan hidran di lapangan telah sesuai SNI 03-1745-2000 (BSNI, 2000c).

Sprinkler. Terdapat sprinkler otomatis yang terpasang pada bangunan gedung RSUD. Area yang terpasang sudah sesuai kebutuhan peruntukannya, kecuali di ruang tertentu seperti toilet, ruang panel listrik, tangga, dan ruang tahan api. Air digunakan adalah air tanah sehingga tidak menyebabkan korosi dan terbebas dari bahan-bahan kimia berbahaya. Penyediaan air berkapasitas 225 liter per menit dengan estimasi mampu menyembur air lebih dari 30 menit. Jarak antara 2 kepala springkler yang ada kurang dari 2,5 meter. Thermatic sprinkler berisi cairan warna merah pada kepala sprinkler dan memiliki kepekaan pada suhu $68^{\circ} \mathrm{C}$. Di RSUD kabupaten Bekasi tidak tersedia sprinkler cadangan untuk mengganti sprinkler yang rusak. Tentunya, hal ini tidak sesuai dengan SNI 03-3989-2000 yang menyebutkan bahwa sejumlah 5 sprinkler cadangan harus tersedia dengan jumlah tidak kurang dari 6 sprinkler cadangan (BSNI, 2000h).

Siamese connection. Siamese connection diletakkan pada jalan masuk dan jalan keluar, lokasinya terjangkau mobil pemadam kebakaran. Siamese connection tidak dilengkapi petunjuk dan penjelasan. Sehingga hal ini tidak sesuai dengan aturan Pd-T-11-2005-C yaitu siamese connection harus diberikan tanda petunjuk yang jelas agar mudah dikenali (BSNI, 2004).

Sistem pemadam luapan. Pada ruang kerja, sistem ini tersedia dengan kesesuaian jenis dan fungsinya. Salah satu alat pendukungnya yaitu heat detector (BSNI, 2000e, 2000f) dan sprinkler (BSNI, 2000h) kecuali di ruang tertentu yang tidak diperbolehkan untuk pemasangannya seperti kakus, dapur, ruang panel listrik, dan APAR.

Pengendali asap. RSUD kabupaten Bekasi belum memiliki sistem pengendali asap, tentunya hal ini tidak sesuai dengan Pd-T-11-2005-C (BSNI, 2000a, 2004; PermenPU, 2008). Ketiadaan sistem pengendali asap ini memang tidak dicantumkan dalam rencana rancangan pembangunan gedung.

Deteksi asap. Sistem deteksi asap belum dimiliki oleh bangunan RSUD kabupaten Bekasi, alat deteksi kebakaran 
JURNAL ILMU KeSEHATAN BHAKTI HUSADA:

HEALTH SCIENCES JouRNAL, VOL. 10 No. 01, DeSEMBER 2020

DOI: $\underline{10.34305 / j i k b h . v 11 i 2.184}$
Ciptaan disebarluaskan di bawah

Lisensi Creative Commons Atribusi-

NonKomersial-BerbagiSerupa 4.0

Internasional yang tersedia dan terpasang adalah deteksi panas atau heat detector (BSNI, 2000e). Dalam rencana rancangan pembangunan gedung RSUD kabupaten Bekasi diketahui bahwa tidak masuknya sistem deteksi asap atau smoke detector dianggap cukup dengan pemasangan heat detector saja.

Pembuangan Asap. Persyaratan PdT-11-2005-C bahwa ruang perlu menyediakan alat penghisap asap dengan kapasitas fan pembuang asap yang disesuaikan (BSNI, 2004; OHSAS, 2007; Ramli, 2010; Rijanto, 2010). Di RSUD kabupaten Bekasi alat yang terpasang hanya ditemukan di gedung $\mathrm{C}$ dan tercatat baru terpasang pada awal tahun 2020 sejak pengajuan alat tahun 2018 oleh pengurus K3.

Lift kebakaran. Pada bangunan RSUD belum tersedia lift penanggulangan jika ada kebakaran. Sesuai Pd-T-11-2005$\mathrm{C}$, keberadaan lift tersebut harus dipasang pada bangunan yang berketinggian minimal 25 m (BSNI, 2000a, 2000d, 2004). Hasil pengamatan diketahui terdapat bangunan rancangan lift pada gedung B RSUD kabupaten Bekasi, namun tidak diketahui catatan laporan hasil uji cobanya yang melibatkan tiga pihak yang harus hadir yaitu, pihak RSUD, pihak PUPR, dan pihak kontraktor. Artinya, status lift kebakaran belum diketahui pasti apakah lift tersebut bisa digunakan sebagai lift kebakaran.

Cahaya darurat dan petunjuk arah. Pemasangan cahaya emergensi harus tersedia di sarana tangga, jalan terusan, dan sepanjang koridor menuju keluar. Pencahayaan darurat otomatis akan beroperasi apabila terjadi pemadaman listrik. Tanda exit (keluar) sangat jelas dan terpasang dekat pintu jalan exit langsung, exit horizontal, dan pintu dari tangga. Sepanjang jalan keluar diberikan tanda yang menunjukkan arah jalur evakuasi yang langsung menuju exit dan keluar bangunan. Baik tanda exit dan jalur evakuasi sangat jelas terlihat dan dapat menyala dalam kegelapan (BSNI, 2000d; Haghani \& Sarvi, 2016).

Listrik darurat. Sumber listrik yang digunakan di RSUD kabupaten Bekasi adalah PLN, generator, dan UPS yang dapat menyala selama dua jam. Instalasi kabel yang digunakan jenis kabel tahan panas dan pemasangannya sudah sesuai prosedur dalam PUIL (BSNI, 2000e, 2004).

Ruang pengendali operasi. Tersedia ruang khusus yang digunakan untuk ruang kontrol didalamnya terdapat CCTV, alat pengendali alarm, dan juga alat pengendali pompa untuk kebakaran. Di bagian bawah tanah bangunan ruang kontrol terdapat 
JURNAL ILMU KeSEHATAN BHAKTI HUSADA:

HEALTH SCIENCES JouRNAL, VOL. 10 No. 01, DeSEMBER 2020

DOI: $\underline{10.34305 / j i k b h . v 11 i 2.184}$
Ciptaan disebarluaskan di bawah

Lisensi Creative Commons Atribusi-

NonKomersial-BerbagiSerupa 4.0

Internasional ground tank untuk pasokan air sprinkler (BSNI, 2000a, 2000b, 2000c, 2000d, 2000e, 2000f, 2000g, 2004).

\section{Sarana Penyelamatan}

Penerapan sarana penyelamatan jiwa yang terdiri dari tiga sub-komponen sebagai berikut:

Jalan Keluar. Pada bangunan RSUD Kabupaten Bekasi di setiap lantai terdapat dua exit dengan ketinggian kurang lebih 2,5 meter. Konstruksi bangunan exit tahan api sehingga terlindung dari bahaya kebakaran. Jarak yang ditempuh pada setiap exit menuju luar bangunan kurang dari 20 meter dari pintu keluar sedangkan jarak rambu exit menuju jalan keluar tidak lebih dari 6 meter (BSNI, 2000d; Haghani \& Sarvi, 2016). Pintu exit tahan api menggunakan pintu ayun yang tidak mengganggu proses evakuasi dan tidak terhalang oleh benda apapun. Jalan keluar langsung menuju ruang terbuka RSUD Kabupaten Bekasi.

Konstruksi Jalan Keluar. Konstruksi jalan keluar dirancang dapat bertahan terhadap api lebih dari 2 jam. Pada jalan keluar bebas dari hambatan tidak terdapat penghalang dan memiliki lebar kurang lebih 2,5 meter (BSNI, 2000a, 2000d; Haghani \& Sarvi, 2016; Ramli, 2010; Rijanto, 2010). Jalan terusan terdapat sistem proteksi berupa APAR, sprinkler, cahaya darurat dan konstruksi kokoh terbuat dari beton. Jalan keluar dirancang untuk memudahkan proses evakuasi sehingga memiliki cukup waktu dalam evakuasi. Petugas kebakaran memiliki akses yang mudah dijangkau untuk proses pemadaman api. Namun ada hal yang belum sesuai dengan Pd-T-112005-C yaitu disebutkan bahwa pada konstruksi jalan keluar dapat mencegah penjalaran asap sedangkan pada bangunan RSUD kabupaten Bekasi memang terdapat sekat dengan konstruksi beton namun tidak terdapat sistem pengendali asap sehingga memungkinkan adanya penjalaran asap pada saat kebakaran.

Landasan Helikopter. Bangunan yang berketinggian minimal $60 \mathrm{~m}$ menurut Pd-T-11-2005-C perlu dibuatkan landasan helikopter. Ketinggian bangunan RSUD kabupaten Bekasi kurang dari $60 \mathrm{~m}$ sehingga tidak diperlukan landasan helikopter.

Nilai Keandalan Keselamatan Bangunan Gedung

Standar pengukuran nilai keandalan pemeriksaan keselamatan kebakaran bangunan gedung telah diatur dalam Pd-T11-2005-C. Pada bangunan gedung di RSUD kabupaten Bekasi, diukur empat 
JURNAL ILMU KESEHATAN BHAKTI HUSADA:

HEALTH SCIENCES JOURNAL, Vol. 10 No. 01, DESEMBER 2020

DOI: $10.34305 / j i k b h . v 11 \mathrm{i} 2.184$
Ciptaan disebarluaskan di bawah Lisensi Creative Commons Atribusi-

NonKomersial-BerbagiSerupa 4.0

Internasional

parameter nilai keandalan keselamatan penyelamatan jiwa, dan sistem proteksi bangunan gedung terhadap kebakaran, aktif dan pasif.

meliputi kelengkapan tapak, sarana

Tabel 2. Penilaian Komponen Kelengkapan Tapak

\begin{tabular}{clccccc}
\hline No & \multicolumn{1}{c}{$\begin{array}{c}\text { KSKB/ SUB } \\
\text { KSKB }\end{array}$} & $\begin{array}{c}\text { Hasil } \\
\text { Penilaian }\end{array}$ & $\begin{array}{c}\text { Standar } \\
\text { Penilaian }\end{array}$ & Bobot (\%) & $\begin{array}{c}\text { Nilai } \\
\text { Kondisi }\end{array}$ & $\begin{array}{c}\text { Jumlah } \\
\text { Nilai }\end{array}$ \\
\hline I. & Kelengkapan Tapak & & & $\mathbf{2 5}$ & & \\
1. & Sumber Air & B & 100 & 27 & 6,75 & \\
2. & Jalan Lingkungan & B & 100 & 25 & 6,25 & \\
3. & Jarak Antar & C & 80 & 23 & 4,6 & $\mathbf{2 3 , 8 5 \%}$ \\
4. & Bangunan & B & 100 & 25 & 6,25 & \\
& Hidran Halaman & & & & & \\
\hline
\end{tabular}

Tabel 3. Penilaian Komponen Sarana Penyelamatan

\begin{tabular}{rlccccc}
\hline No & KSKB/ SUB & $\begin{array}{l}\text { Hasil } \\
\text { KSKB }\end{array}$ & $\begin{array}{l}\text { Standar } \\
\text { Penilaian }\end{array}$ & Bobot (\%) & $\begin{array}{l}\text { Nilai } \\
\text { Kondisi }\end{array}$ & Jumlah Nilai \\
\hline I. & Sarana Penyelamatan & & & $\mathbf{2 5}$ & & \\
1. & Jalan Keluar & B & 100 & 38 & 9,5 & \\
2. & $\begin{array}{l}\text { Konstruksi Jalan } \\
\quad\end{array}$ & Celuar & 80 & 35 & 7 & $\mathbf{2 3 , 2 5 \%}$ \\
3. & $\begin{array}{l}\text { Landasan } \\
\text { Helikopter }\end{array}$ & B & 100 & 27 & 6,75 & \\
\hline
\end{tabular}

Tabel 4. Penilaian Komponen Sistem Proteksi Aktif

\begin{tabular}{|c|c|c|c|c|c|c|}
\hline No & $\begin{array}{l}\text { KSKB/ SUB } \\
\text { KSKB } \\
\end{array}$ & $\begin{array}{l}\text { Hasil } \\
\text { Penilaian }\end{array}$ & $\begin{array}{l}\text { Standar } \\
\text { Penilaian }\end{array}$ & Bobot (\%) & $\begin{array}{l}\text { Nilai } \\
\text { Kondisi }\end{array}$ & $\begin{array}{l}\text { Jumlah } \\
\text { Nilai }\end{array}$ \\
\hline I. $\mathrm{S}$ & tem Proteksi Aktif & & & 24 & & \multirow{14}{*}{$17,04 \%$} \\
\hline 1. & Deteksi dan Alarm & B & 100 & 8 & 1,92 & \\
\hline 2. & Siamese & $\mathrm{C}$ & 80 & 8 & 1,54 & \\
\hline 3. & $\begin{array}{l}\text { Connection } \\
\text { Pemadam Api } \\
\text { Ringan }\end{array}$ & B & 100 & 8 & 1,92 & \\
\hline 4. & Hidran Gedung & B & 100 & 8 & 1,92 & \\
\hline 5. & Sprinkler & $\mathrm{C}$ & 80 & 8 & 1,54 & \\
\hline 6. & $\begin{array}{l}\text { Sistem Pemadam } \\
\text { Luapan }\end{array}$ & B & 100 & 7 & 1,68 & \\
\hline 7. & Pengendali Asap & K & 0 & 8 & 0 & \\
\hline 8. & Deteksi Asap & $\mathrm{K}$ & 0 & 8 & 0 & \\
\hline 9. & Pembuangan Asap & K & 60 & 7 & 1,00 & \\
\hline 10. & Lift Kebakaran & K & 0 & 7 & 0 & \\
\hline 11. & Cahaya Darurat & B & 100 & 8 & 1,92 & \\
\hline 12. & Listrik Darurat & B & 100 & 8 & 1,92 & \\
\hline 13. & $\begin{array}{l}\text { Ruang Pengendali } \\
\text { Operasi }\end{array}$ & B & 100 & 7 & 1,68 & \\
\hline
\end{tabular}


Tabel 5. Hasil Penilaian Sistem Proteksi Pasif

\begin{tabular}{|c|c|c|c|c|c|c|}
\hline No & KSKB/ SUB KSKB & $\begin{array}{l}\text { Hasil } \\
\text { Penilaian }\end{array}$ & $\begin{array}{l}\text { Standar } \\
\text { Penilaian }\end{array}$ & $\begin{array}{l}\text { Bobot } \\
(\%)\end{array}$ & $\begin{array}{l}\text { Nilai } \\
\text { Kondisi }\end{array}$ & $\begin{array}{l}\text { Jumlah } \\
\text { Nilai }\end{array}$ \\
\hline & stem Proteksi Pasif & & & 26 & & \\
\hline 1. & $\begin{array}{l}\text { Ketahanan Api } \\
\text { Struktur Bangunan }\end{array}$ & B & 100 & 36 & 9,36 & \\
\hline 2. & $\begin{array}{l}\text { Kompartemenisasi } \\
\text { Ruang }\end{array}$ & B & 100 & 32 & 8,32 & $24,34 \%$ \\
\hline 3. & Perlindungan Bukaan & $\mathrm{C}$ & 80 & 32 & 6,66 & \\
\hline
\end{tabular}

Tabel 6. Tingkat Keandalan Sistem Keselamatan Bangunan Gedung Terhadap

Kebakaran

\begin{tabular}{llc}
\hline No. & Komponen KSKB & Nilai Kondisi KSKB \\
\hline 1. & Kelengkapan Tapak & $23,85 \%$ \\
2. & Sarana Penyelamatan & $23,25 \%$ \\
3. & Sistem Proteksi Aktif & $17,04 \%$ \\
4. & Sistem Proteksi Pasif & $23,34 \%$ \\
\hline Jumlah NKSKB & $\mathbf{8 7 , 4 8 \%}$ \\
\hline
\end{tabular}

Dalam menilai kondisi pada setiap bagian bangunan harus sesuai pedoman PdT-11-2005-C. Tersedia tiga nilai kondisi untuk komponen proteksi kebakaran bangunan, yaitu: BAIK = "B", SEDANG atau CUKUP $=$ "C $"$ dan KURANG $=$ "K" (Ekuivalensi nilai $\mathrm{B}=100, \mathrm{C}=80$ dan $\mathrm{K}=$ 60). Kriteria-kriteria diatas sebagai acuan praktis untuk petugas pengelola bangunan dalam menilai kondisi proteksi kebakaran bangunan (BSNI, 2004; PermenPU, 2008).

\section{Nilai Kondisi Komponen} Kelengkapan Tapak. Nilai Kondisi kelengkapan tapak yang terdiri dari sumber air, jalan lingkungan, jarak antar bangunan, dan hidran halaman (BSNI, 2000a, 2000c, 2000d). Pada tabel 2 diketahui hasil perhitungan nilai kondisi komponen kelengkapan tapak adalah $23,85 \%$ atau mendekati nilai bobot maksimal $25 \%$.

Penilaian Komponen Sarana Penyelamatan. Untuk mengetahui hasil pemenuhan penilaian komponen sarana penyelamatan jiwa sebelumnya sudah dilakukan observasi dan dibandingkan dengan peraturan yang berlaku (BSNI, 2000d; Hidayat et al., 2017; Permenakertrans, 1980; Rijanto, 2010; Simangunsong, 2017). Kemudian selanjutnya dilakukan perhitungan untuk mendapatkan nilai kondisi komponen sarana penyelamatan jiwa yang memiliki bobot maksimal 25\%. Hasil dari perhitungan tersebut dapat dilihat pada tabel 3. Hasil penilaian komponen sarana penyelamatan menunjukkan hasil 23,25\% dari nilai bobot maksimal $25 \%$. Hal tersebut 
JURNAL ILMU KeSEHATAN BHAKTI HUSADA:

HEALTH SCIENCES JouRNAL, VOL. 10 No. 01, DeSEMBER 2020

DOI: $\underline{10.34305 / j i k b h . v 11 i 2.184}$
Ciptaan disebarluaskan di bawah

Lisensi Creative Commons Atribusi-

NonKomersial-BerbagiSerupa 4.0

Internasional. dikarenakan sub komponen landasan

helikopter masuk dalam kategori baik sedangkan konstruksi jalan keluar bernilai cukup hal ini dikarenakan ada kriteria yang belum memenuhi persyaratan yaitu tidak tersedianya pengendali asap sehingga tidak dapat mencegah penjalaran asap kebakaran.

Penilaian Komponen Sistem

Proteksi Aktif. Hasil nilai dari tiga belas subkomponen menunjukkan bahwa bobot komponen sistem proteksi aktif yaitu sebesar $24 \%$. Nilai kondisi diperoleh dari tiap sub komponen dan hasil akhir nilai kondisi dari komponen sistem proteksi aktif (Ekiyanto, 2018; PermenPU, 2008; Putri, 2016; Simangunsong, 2017). Pada tabel 4 diketahui nilai kondisi sistem proteksi aktif sebesar 17,04\%, sementara bobot komponen sistem proteksi aktif yang sesuai ketentuan adalah sebesar 24\%. Hal ini terjadi karena ada sub komponen yang tidak tersedia pada bangunan RSUD kabupaten Bekasi yaitu pengendali asap, deteksi asap dan lift kebakaran sehingga nilainya 0 . Pada sub komponen lift kebakaran gedung B belum diketahui apakah telah berfungsi. Ketidakjelasan status lift kebakaran ini masuk kategori $\mathrm{K}$ dengan sub komponen tidak tersedia. Pada subkomponen pembuangan asap juga belum diketahui keberfungsiannya sehingga mendapat nilai
$\mathrm{K}=60$, selanjutnya sub komponen sprinkler dan siamese connection mendapatkan nilai $\mathrm{C}=.80$ dikarenakan ada kriteria yang belum memenuhi persyaratan yaitu pada sprinkler tidak terdapat cadangan dan pada siamese connection tidak terdapat tanda petunjuk yang jelas.

Penilaian Komponen Sistem Proteksi Pasif. Terdapat tiga sub-komponen yang harus dinilai, yaitu perlindungan bukaan, ketahanan api struktur bangunan, dan kompartemenisasi ruangan (BSNI, 2000b; Hidayat et al., 2017; Kowara, R. A., \& Martiana, 2017; Rahman, 2017; Vanisia, 2017). Hasil penilaian komponen sistem proteksi pasif di RSUD kabupaten Bekasi menunjukkan angka $24,34 \%$ dari bobot 26\% (Tabel 5). Hal tersebut dikarenakan, pada sub-komponen perlindungan bukaan sebenarnya sudah memenuhi kriteria yang dipersyaratkan, yaitu perlindungan bukaan, penyediaan bukaan vertikal dari dinding tertutup, dan pemberian penyetop api. RSUD kabupaten Bekasi memiliki sarana proteksi pada bukaan pintu kebakaran, jendela kebakaran, pintu penahan asap, dan penutup api sesuai dengan standar pintu kebakaran. Hasil pengamatan tidak ditemukan ketersediaan komponen jendela kebakaran sesuai dengan yang dipersyaratkan oleh Pd-T-11-2005-C. 
JURNAL ILMU KeSEHATAN BHAKTI HUSADA:

HEALTH SCIENCES JouRnal, VOL. 10 No. 01, DeSEMBER 2020

DOI: $\underline{10.34305 / j i k b h . v 11 i 2.184}$
Ciptaan disebarluaskan di bawah

Lisensi Creative Commons Atribusi-

NonKomersial-BerbagiSerupa 4.0

Internasional

\section{Kesimpulan}

\section{Hasil Nilai Keandalan Bangunan Gedung RSUD}

Nilai kondisi pada masing-masing komponen, yaitu kelengkapan tapak, sarana penyelamatan, sistem proteksi aktif, dan sistem proteksi diperoleh melalui kegiatan observasi. Selanjutnya, dilakukan penjumlahan nilai kondisi tiap komponen untuk mendapatkan hasil akhir berupa nilai Keandalan Sistem Keselamatan Bangunan (NKSKB) (Asyroffi, 2017; Ekiyanto, 2018; Hidayat et al., 2017; Kowara, R. A., \& Martiana, 2017; Putri, 2016; Rahman, 2017; Safaat, 2015; Septiadi et al., 2014; Simangunsong, 2017). Pada tabel 6 disajikan hasil nilai keandalan sistem keselamatan bangunan gedung terhadap kebakaran RSUD kabupaten Bekasi. Tingkat keandalan sistem keselamatan bangunan gedung terhadap kebakaran 87,48\%. Berdasarkan pedoman Pd-T-112005-C maka nilai tersebut berkategori "Baik" (B). Hal ini membuktikan bahwa RSUD kabupaten Bekasi memiliki komitmen akan keselamatan dan kesehatan kerja bagi karyawan, pasien dan pengunjung rumah sakit terutama dalam pencegahan dan penanggulangan bahaya kebakaran.
Sistem proteksi aktif kebakaran, sarana penyelamatan jiwa, dan nilai keandalan sistem keselamatan bangunan gedung di RSUD Kabupaten Bekasi disimpulkan bahwa kondisi sub-komponen sistem proteksi aktif di RSUD sebagian besar telah sesuai sedangkan pada pemasangan alat ditemukan sebagian kecil instalasi tidak sesuai. Selain itu, keberadaan komponen proteksi aktif belum merata terpasang pada setiap bangunan gedung di RSUD. Namun begitu, nilai kondisi komponen sistem proteksi aktif di RSUD kabupaten Bekasi bernilai BAIK. Sarana penyelamatan jiwa dari sub komponen jalan keluar berkategori BAIK "B" sementara sub-komponen konstruksi jalan keluar masuk berkategori CUKUP "C". Secara keseluruhan nilai kondisi sarana penyelamatan jiwa pada bangunan gedung RSUD bernilai BAIK. Tingkat keandalan keselamatan kebakaran bangunan gedung di RSUD Kabupaten Bekasi menunjukkan kategori BAIK (B). Saran penelitian direkomendasikan perbaikan pada sistem deteksi asap dan alat pengendali asap sehingga dapat bekerja bersinergi apabila deteksi asap menyala. Perlunya dilengkapi pemasangan alat pembuangan asap secara bertahap khususnya di gedung B RSUD 
JURNAL ILMU KeSEHATAN BHAKTI HUSADA:

HeAlth SCIENCES JouRnal, Vol. 10 No. 01, Desember 2020

DOI: $\underline{10.34305 / j i k b h . v 11 i 2.184}$
Ciptaan disebarluaskan di bawah

Lisensi Creative Commons Atribusi-

NonKomersial-BerbagiSerupa 4.0

Internasional
Kabupaten Bekasi. Terakhir untuk antisipasi bencana, dilakukan commissioning test terhadap lift kebakaran.

\section{Ucapan Terima Kasih}

Ibu PS. Dyah Prinajati, ST, MT, dan bapak ibu di lingkungan Program Studi Teknik Lingkungan Fakultas Teknik Universitas Sahid Jakarta yang telah banyak membantu dan mendukung pada kegiatan penelitian ini.

\section{Referensi}

Asyroffi, A. H. (2017). Perencanaan Sistem Tanggap Darurat Sebagai Upaya pengendalian Pada KebakPran di PT. Anugerah Widjaja Mandiri Chemindo. Skripsi. Universitas Sahid Jakarta, Jakarta.

BSNI. (2000a). SNI 03-1735-2000 Tata cara perencanaan akses bangunan dan akses lingkungan untuk pencegahan bahaya kebakaran pada bangunan rumah dan gedung. In. Jakarta: Badan Standar Nasional Indonesia.

BSNI. (2000b). SNI 03-1736-2000 Tata cara perencanaan sistem proteksi pasif untuk pencegahan bahaya kebakaran pada bangunan rumah dan gedung. In. Jakarta: Badan Standar Nasional Indonesia.

BSNI. (2000c). SNI 03-1745-2000 Tata cara perencanaan dan pemasangan hidran untuk pencegahan bahaya kebakaran pada bangunan gedung. In. Jakarta: Badan Standar Nasional Indonesia.
BSNI. (2000d). SNI 03-1746-2000 Tata cara perencanaan dan pemasangan sarana jalan keluar untuk penyelamatan terhadap bahaya kebakaran pada gedung. In. Jakarta: Badan Standar Nasional Indonesia.

BSNI. (2000e). SNI 03-3985-2000 Tata cara perencanaan, pemasangan dan pengujian sistem deteksi dan alarm kebakaran untuk pencegahan bahaya kebakaran pada bangunan gedung. In. Jakarta: Badan Standar Nasional Indonesia.

BSNI. (2000f). SNI 03-3986-2000 Instalasi alarm kebakaran otomatik. In. Jakarta: Badan Standar Nasional Indonesia.

BSNI. (2000g). SNI 03-3989-2000 Tata cara perencanaan dan pemasangan sistem sprinkler otomatis untuk pencegahan bahaya kebakaran pada bangunan gedung. In. Jakarta: Badan Standar Nasional Indonesia.

BSNI. (2004). SNI 03-7017.2-2004 Pemeriksaan keselamatan kebakaran pada bangunan gedung. In. Jakarta: Badan Standar Nasional Indonesia.

Ekiyanto, R. T. (2018). Studi Deskriptif Terhadap Potensi Penerapan Sistem Evakuasi Proteksi Kebakaran di PT. Tokai Rika Indonesia. Skripsi. Universitas Sahid Jakarta, Jakarta.

Haghani, M., \& Sarvi, M. (2016). Human Exit Choice In Crowded Built Environments: Investigating Underlying Behavioural Differences Between Normal Egress and Emergency Evacuations. Fire Safety Journal, 85, 1-9.

Hambyah, R. F. (2016). Evaluasi 
JURNAL ILMU KeSEHATAN BHAKTI HUSADA:

HEALTH SCIENCES JOURNAL, VOL. 10 No. 01, DESEMBER 2020

DOI: $\underline{10.34305 / j i k b h . v 11 i 2.184}$
Ciptaan disebarluaskan di bawah

Lisensi Creative Commons Atribusi-

NonKomersial-BerbagiSerupa 4.0

Internasional
Pemasangan APAR dalam Sistem Tanggap Darurat Kebakaran di Gedung Bedah RSUD Dr. Soetomo Surabaya. The Indonesian Journal of Occupational Safety and Health, 5(1), 41-50.

Hidayat, D. A., Suroto, S., \& Kurniawan, B. (2017). Evaluasi Keandalan Sistem Proteksi Kebakaran Ditinjau Dari Sarana Penyelamatan dan Sistem Proteksi Pasif Kebakaran Di Gedung Lawang Sewu Semarang. Jurnal Kesehatan Masyarakat, 5(5), 134-145.

KepmenNaker. (1999). Keputusan Menteri Tenaga Kerja RI No.186/MEN/1999 Tentang Unit Penanggulangan Kebakaran di Tempat Kerja.

Kowara, R. A., \& Martiana, T. (2017). Analisis Sistem Proteksi Kebakaran Sebagai Upaya Pencegahan Dan Penanggulangan Kebakaran. Jurnal Manajemen Kesehatan Yayasan RS. Dr. Soetomo, 3(1), 69-84.

OHSAS. (2007). Tentang Sistem Manajemen Keselamatan dan Kesehatan Kerja. Jakarta : Occupational Health and Safety Assessment Series.

Permenakertrans. (1980). Peraturan Menteri Tenaga Kerja dan Transmigrasi No. Per 04/Men/1980 Tentang Syarat-Syarat Pemasangan Dan Pemeliharaan Alat Pemadam Api Ringan.

Permenkes. (2010). Peraturan Menteri Kesehatan Republik Indonesia No. 340/MENKES/PER/III/2010 Tentang Klasifikasi Rumah Sakit.

PermenPU. (2008). Permen PU No 26
PRT/M/2008, Persyaratan Teknis Sistem Proteksi Kebakaran Pada Bangunan Gedung dan Lingkungan. Peraturan Menteri Pekerjaan Umum, 26.

Putri, O. A. (2016). Evaluasi Penerapan Sistem Proteksi Kebakaran Aktif Di PT Reckitt Benckiser Indonesia Semarang Factory Departemen Pra Produksi. Skripsi. Universitas Negeri Semarang, Semarang.

Rahman, N. V. (2017). Evaluasi Sistem Proteksi Pasif Kebakaran Bangunan (Studi Kasus: Millennium ICT Centre).

Ramli, S. (2010). Petunjuk Praktis Manajemen Kebakaran (Fire Management). Jakarta: Dian Rakyat, 2.

Rijanto, B. B. (2010). Kebakaran dan Perencanaan Bangunan. Jakarta: Mitra Wacana Media.

Safaat, L. M. (2015). Gambaran Tingkat Keandalan Sistem Proteksi Kebakaran Bangunan Gedung IGD Rumah Sakit Umum Pusat Fatmawati Jakarta. Skripsi. Universitas Islam Negeri Syarif Hidayatullah, Jakarta.

Septiadi, H., Sunarsih, E., \& Camelia, A. (2014). Analisis Sistem Proteksi Kebakaran Pada Bangunan Gedung Dan Lingkungan Di Universitas Sriwijaya Kampus Inderalaya. Jurnal Ilmu Kesehatan Masyarakat, 5(1).

Simangunsong, N. (2017). Analisis Sistem Proteksi Aktif Dan Sarana Penyelamatan Jiwa Sebagai Upaya Penanggulangan Kebakaran Di Rumah Sakit Vita Insani Pematangsiantar Tahun 2017. Skripsi. Universitas 
JURNAL ILMU KESEHATAN BHAKTI HUSADA:

HEALTh SCIENCES JoURNAL, Vol. 10 No. 01, DESEMBER 2020

DOI: $10.34305 / j i k b h . v 11 i 2.184$

Sumatera Utara, Medan.

Sugiyono. (2013). Metode Penelitian Kuantitatif Kualitatif dan R\&D. Bandung : Alfabeta.

Sukwika, T. (2018). Peran Pembangunan Infrastruktur Terhadap Ketimpangan Ekonomi Antar Wilayah di Indonesia.
Ciptaan disebarluaskan di bawah Lisensi Creative Commons Atribusi-
Jurnal Wilayah Dan Lingkungan, 6(2), 115-130.

Vanisia, S. (2017). Analisis Sarana Proteksi Kebakaran dan Sistem Tanggap Darurat di PT. Genero Pharmaceuticals. Skripsi. Universitas Sahid Jakarta, Jakarta. 